\begin{tabular}{|l|l|l||}
\hline \multicolumn{2}{|c|}{ PublisherInfo } \\
\hline \hline PublisherName & $:$ & BioMed Central \\
\hline \hline PublisherLocation & $:$ & London \\
\hline \hline PublisherImprintName & $:$ & BioMed Central \\
\hline \hline
\end{tabular}

\title{
Regulatory T cells and GVHD
}

\begin{tabular}{|l|l|l||}
\hline \multicolumn{2}{|c|}{ ArticleInfo } \\
\hline \hline ArticleID & $:$ & 79 \\
\hline \hline ArticleDOI & $:$ & $10.1186 /$ ar-2001-68284 \\
\hline \hline ArticleCitationID & $:$ & 68284 \\
\hline \hline ArticleSequenceNumber & $:$ & 36 \\
\hline \hline ArticleCategory & $:$ & Paper Report \\
\hline \hline ArticleFirstPage & $:$ & 1 \\
\hline \hline ArticleLastPage & $:$ & 4 \\
\hline \hline & & RegistrationDate : 2001-7-27 \\
ArticleHistory & $:$ & Received \\
\hline ArticleCopyright & $:$ & Biomed Central Ltd2001 \\
\hline \hline ArticleGrants & $:$ & \\
\hline \hline ArticleContext & $:$ & 130753311 \\
\hline \hline
\end{tabular}


Aff1 University of Queensland, Australia

\section{Keywords}

GVHD, phenotype, regulatory T cells

\section{Context}

So-called 'suppressor' or 'regulatory' T cells are thought to prevent activation, in the periphery, of two cell types: antigen-presenting cells (APCs) that present endogenously processed self-antigens, and selfreactive $\mathrm{T}$ cells that have escaped thymic deletion (see Additional information [1]). It was found that $\mathrm{T}$ cells with the phenotype $\mathrm{CD} 4{ }^{+} \mathrm{CD} 25^{+}$can prevent autoimmune disease in the context of neonatal thymectomy when adoptively transferred (see Additional information [2]). This paper investigated whether $\mathrm{T}$ cells of the same phenotype could transfer tolerance for alloantigen in both in vitro and in vivoallogeneic T-cell transfer models of graft-versus-host disease (GVHD).

\section{Significant findings}

T-cell proliferation occurred in vitro when APCs were incubated with allogeneic T cells in a mixed lymphocyte reaction (MLR). When CD40L was blocked, tolerance to the alloantigen occurred. When the T cells were restimulated with the same APCs in a secondary MLR, proliferation was suppressed. Depletion of $\mathrm{CD} 4{ }^{+} \mathrm{CD} 25^{+} \mathrm{T}$ cells prior to the primary MLR abrogated the induction of hyporesponsiveness to alloantigen rechallenge in the secondary MLR after anti-CD40L costimulatory blockade in the primary allogeneic MLR. Moreover, purified $\mathrm{CD} 4^{+} \mathrm{CD} 25^{+} \mathrm{T}$ cells in high concentrations suppressed a primary MLR.

In vivo, mice inoculated with T cells from an MLR cultured without blocking antibody all died from GVHD, whereas adoptive transfer of T cells cultured in allogeneic MLR in the presence of either antiB7 or anti-CD40L monoclonal antibody did not induce GVHD. In a similar fashion to the in vitro experiments, depletion of $\mathrm{CD} 4{ }^{+} \mathrm{CD} 25^{+} \mathrm{T}$ cells from MLR before transfer abrogated protection against GVHD. 


\section{Comments}

These data demonstrate that $\mathrm{CD} 4{ }^{+} \mathrm{CD} 25^{+} \mathrm{T}$ cells regulate other $\mathrm{T}$ cells in vitro and in vivo. The studies are consistent with a large body of literature demonstrating the regulatory capacity of this $\mathrm{T}$ cell subset, and broaden the concept of their capacity for regulation, to alloantigen. As both $\mathrm{CD} 4{ }^{+} \mathrm{CD} 25^{+}$and $\mathrm{CD} 25^{-} \mathrm{T}$ cells expressed CD40L, the data suggest (surprisingly) that blockade of CD40 or B7 costimulation has no effect on effector function of $\mathrm{CD} 4^{+} \mathrm{CD} 25^{-} \mathrm{T}$ cells, but that inhibition of either of these pathways can induce the $\mathrm{CD} 4^{+} \mathrm{CD} 25^{+}$regulatory subset.

Although intriguing, the in vivo model studied is a very limited one, essentially carrying out an MLR in an animal. It will be of physiological relevance to determine whether tolerance induced in vivowith anti-CD40L or anti-B7 (in grafting and autoimmune models) is mediated by similar mechanisms. For example, could these antibodies block autoimmune diseases in neonatal thymectomy models? From a clinical perspective, a testable hypothesis is that the more the autoimmune disease patient is CD4-deficient (depleted of regulatory T cells), the harder it is to induce remission/tolerance - a concept with implications for stem cell grafting in autoimmune disease.

\section{Methods}

Adoptive transfer, MLR

\section{Additional information}

1. Roncarolo MG, Levings MK: The role of different subsets of $\mathrm{T}$ regulatory cells in controlling autoimmunity.Curr Opin Immunol 2000, 12:676-683 (PubMed abstract).

2. Sakaguchi S, Sakaguchi N, Asano M, Itoh M, Toda M: Immunologic self-tolerance maintained by activated $\mathrm{T}$ cells expressing IL-2 receptor alpha-chains (CD25). Breakdown of a single mechanism of self-tolerance causes various autoimmune diseases.J Immиnol 1995, 155:1151 (PubMed abstract). 


\section{References}

1. Taylor PA, Noelle RJ, Blazar BR: $\mathrm{CD} 4{ }^{+} \mathrm{CD} 25^{+}$immune regulatory cells are required for induction of tolerance to alloantigen via costimulatory blockade. J Exp Med. 2001, 193: 1311-1317.

This PDF file was created after publication. 